Available online at JECE (Journal of Early Childhood Education)

Website: http://journal.uinjkt.ac.id/index.php/jece

Permalink/DOI: http://dx.doi.org/10.15408/jece.v2i1.14336

JECE, 2 (1), Juni 2020, 37-48

\title{
PENINGKATAN KEMAMPUAN MOTORIK HALUS MELALUI KEGIATAN MOZAIK PADA SISWA KELOMPOK B
}

\author{
Qomariah, Leny Marlina, Lidia Oktamarina \\ Universitas Islam Negeri Raden Fatah Palembang, Indonesia \\ corresponding e-mail: qomariahduatujuh@gmail.com
}

\begin{abstract}
The undeveloped child's fine motor ability is the background for this research. The problems in this study were child's undevelopment ability to control fingers and hands, undevelopment of skills using media with the coordination between eyes and hands. The subject of his research was the B3 group of 18 children. This was based on action research method. It used the Kemmis \& McTaggart Research design which consists of planning, observation and reflection actions. There were two cycles with four times meeting in each cycle. Data used in the observation were field records, interview notes and documentation notes. The techniques of data analysis in this study were qualitative data analysis and quantitative data analysis. The results showed that in the pre-cycle phase, the child's fine motor ability level reached $47.66 \%$, whereas after using mozaic activities in cycle 1 it reached until $59.91 \%$ and in cycle 2 it reached to $80.08 \%$. It can be concluded that there is a significant increase in the child's fine motor ability through mosaic activities.
\end{abstract}

Keywords: Improvement, Fine Motor, Mozaic Activities

\begin{abstract}
Abstrak
Penelitian ini dilatarbelakangi belum berkembangnya kemampuan motorik halus anak. Masalah dalam penelitian ini belum berkembangnya kemampuan dalam mengontrol jarijemari, belum berkembangnya ketangkasan jari-jemari dan tangan, serta belum berkembangnya keterampilan menggunakan media dengan koordinasi antara mata dan tangan. Subjek penelitiannya yaitu kelompok B3 yang berjumlah 18 anak. Penelitian ini merupakan penelitian tindakan. Menggunakan desain penelitian Kemmis \& McTaggart yang terdiri dari perencanaan, tindakan observasi dan refleksi. Terdapat dua siklus dan dalam satu siklusnya empat kali pertemuan. Dalam mengumpulkan data digunakan adalah observasi dimana terdapat catatan lapangan, catatan wawancara dan catatan dokumentasi. Teknik analisis data dalam penelitian ini menggunakan analisis data kualitatif dan analisis data kuantitatif. Hasil penelitian menunjukkan bahwa pada tahap prasiklus tingkat kemampuan motorik halus anak mencapai angka persentase $47,66 \%$ sedangkan setelah menggunakan kegiatan mozaik pada siklus I mencapai angka persentase 59,91\% dan pada siklus II mencapai angka persentase $80,08 \%$. Dapat disimpulkan bahwa adanya peningkatan yang cukup signifikan pada kemampuan motorik halus anak melalui kegiatan mozaik.
\end{abstract}

Kata Kunci: Peningkatan, Motorik Halus, Kegiatan Mozaik 


\section{Pendahuluan}

Dalam pasal 28 ayat 1 UU No. 20 tahun 2003 tentang Sistem Pendidikan Nasional disebutkan bahwa anak usia dini adalah anak yang masuk dalam rentang usia 0-6 tahun. Pendidikan Anak Usia Dini (PAUD) adalah suatu upaya pembinaan yang ditujukan kepada anak sejak lahir sampai dengan usia enam tahun yang dilakukan melalui pemberian rangsangan pendidikan untuk membantu pertumbuhan dan perkembangan jasmani dan rohani agar anak memiliki kesiapan dalam memasuki pendidikan lebih lanjut. PAUD dapat diselenggarakan melalui jalur pendidikan formal, nonformal, dan/atau informal. PAUD merupakan suatu wadah bagi anak usia 0-6 tahun dalam pemberian stimulasi pendidikan dimana membantu anak dalam proses pertumbuhan dan perkembangannya sebagai pembentukan karakter bagi anak usia dini dan juga agar perkembangan anak berkembang sesuai dengan tahapan usianya.

PAUD diselenggarakan sebelum jenjang pendidikan dasar. PAUD pada jalur pendidikan formal berbentuk Taman Kanak-kanak (TK), Raudhatul Athfal (RA), atau bentuk lain yang sederajat. Sedangkan PAUD pada jalur pendidikan nonformal berbentuk Kelompok Bermain (KB), Taman Penitipan Anak (TPA), atau bentuk lain yang sederajat. Kemudian PAUD pada jalur pendidikan informal berbentuk pendidikan keluarga atau pendidikan yang diselenggarakan oleh lingkungan Pendidikan anak usia dini haruslah dapat dikemas dan dimuat dengan berbagai permainan dan kegiatan yang menyenangkan agar dapat menjadikan dunia anak berwarna pada proses pembelajaran serta membuat anak tidak bosan. Hal ini bertujuan agar proses pembelajaran yang diberikan lebih bermakna dan juga dapat membahagiakan bagi anak sehingga potensi dan kwalitas yang dimiliki anak dapat berkembang secara keseluruhan dan juga agar dapat berkembang secara optimal sesuai dengan tujuan pendidikan.

Pada masa usia dini yakni usia 0-6 tahun, dimana anak mengalami masa keemasan (golden age) yang merupakan masa yang sangat berharga untuk kehidupan selanjutnya dan juga dimana anak mulai peka atau sensitif dalam menerima berbagai stimulasi atau rangsangan yang diberikan (Devi, Fleer, and Li 2018). Masa peka pada setiap masing-masing anak berbeda antara satu dengan yang lain, semua tergantung dari pemberian stimulasi dan juga pengalaman yang didapatkan anak selama proses pembelajaran maupun proses bermain sehari-hari (Duncan and Sojourner, 2013; Sheridan and Kelly, 2012; Mcintyre and Phaneuf, 2017). Anak usia dini merupakan sosok insan yang masih memiliki sifat bermain yang sangat tinggi (Munroe and MacLellan-Mansell, 2013; Fleer, 2009; Ernst, 2012) . Oleh karena itu, kebebasan berimajinasi menjadikan dirinya memiliki keunikan tersendiri dibandingkan orang dewasa (Rushton, 2011). Kegemarannya bermain seringkali menghadirkan suara-suara maupun gerak- gerik tubuh yang indah atau ekspresif dengan gaya yang spesifik. Semakin bertambahnya umur, seorang anak akan 
berkembang melalui suatu rangkaian tingkatan yang bertahap dan sifat-sifat fisik akan berubah serta keterampilan baru akan dipengaruhi dan disempurnakan.

Perkembangan motorik sangat tergantung pada proses kematangan anak usia dini sebelumnya yang juga tergantung dari proses belajar dan pengetahuan serta pengalaman anak (Dehghan et al., 2017; Taverna et al., 2020). Pengalaman masa kanak-kanak akan sangat bermanfaat pada masa dewasa, diantaranya kemampuan dalam memecahkan masalah baik dalam bentuk keseharian maupun dalam bentuk kemampuan-kemampuan fisik (Mulyani, 2018). Segala bentuk stimulasi yang didapatkan anak dan juga pengalaman-pengalaman yang ia dapatkan melalui bermain akan berdampak pada pertumbuhan dan perkembangannya di masa datang. Semakin baik stimulasi dan pengalaman yang ia dapatkan, akan semakin baik pula pola pertumbuhan dan perkembangannya ketika ia dewasa nanti. Terlebih jika anak senang bergerak dan energik dalam melakukan aktivitas apapun, akan mempengaruhi perkembangan fisiknya sehingga membuat perkembangan fisiknya berkembang sangat baik apabila mendapatkan stimulasi yang tepat (Dehghan et al., 2017). Proses pengalaman yang sangat menentukan perkembangan motorik anak melalui bermain dan kegiatan yang dapat mendorong kreativitas dan tumbuh kembang anak, baik pertumbuhan fisik motoriknya maupun aspek perkembangan lainnya (Fischer, Suggate, and Stoeger, 2020). Maka akan semakin membuat anak menjadi manusia yang bermanfaat dan juga memudahkannya dalam mengurus dirinya sendiri maupun berinteraksi dengan orang lain (Brian et al. 2019).

Masa kanak-kanak diharapkan merupakan masa-masa yang bahagia bagi anak. Masa kanak-kanak yang bahagia dapat menjamin paling tidak lebih dari separuh dari keberhasilannya di masa dewasa. Karena masa-masa ini adalah peletakan dasar dalam keberhasilan kelak di usia dewasa, peletak dasar dalam perkembangan kognitif, bahasa, emosi kepribadian, sosial, spiritual dan fisiknya. Anak yang sehat dan bahagia akan tampak dari penampilan fisik yang sehat, gerak gerik yang energik, motivasi yang kuat dan memiliki rasa ingin tahu yang tinggi sebagai cerminan dari kondisi fungsi intelektual dan emosinya. Sebaliknya, ketidakbahagiaan pada masa-masa kecil berakibat pada ketidakmatangan anak dalam aspek fisik, psikis, emosi, bahasa, kognitif dan kepribadiannya (Mutiah, 2010). Masa usia dini tentu sangat menentukan kepribadian serta perkembangan hidupnya untuk kedepan harinya. Jika dalam kehidupan sehari-hari anak mendapatkan yang segala yang dibutuhkannya, baik kebutuhan jasmani maupun rohaninya maka akan baik pula proses kematangan hidupnya. Kebahagiaan anak sangat penting bagi proses kematangan perkembangannya.

Kondisi fisik yang sehat, maka pemberian stimulasi yang efektif akan dapat mengembangkan kemampuan-kemampuan dan potensinya secara lebih baik. Pemberian stimulasi merupakan perangsangan yang datang dari luar lingkungan diri anak. Stimulasi ini sangat penting dalam tumbuh kembang anak. Stimulasi 
dapat berfungsi sebagai pendorong dan penguat bagi perkembangan anak secara optimal. Anak belajar dari seluruh panca inderanya, melalui berbagai macam alatalat inderanya. Indera penglihatan, indera penciuman, indera perabaan, indera pendengaran, kekuatan motorik halus maupun motorik kasarnya (tangan dan jarijarinya, kakinya) serta kemampuan berpikir, bernalar, mengingat dan memproses segala informasi yang diperolehnya dari lingkungan (Mutiah, 2010). 6 aspek perkembangan akan berkembang dengan baik jika proses yang dilalui anak tersebut dapat mendukung dalam proses tumbuh kembangnya. Proses yang pengalaman dan stimulasi yang dilalui anak tidak terlepas dari peran serta orang tua, guru dan juga teman yang ada disekitar anak. Proses stimulasi yang baik akan mendukung semua aspek perkembangan anak, dan juga aspek perkembangan tersebut sangat penting bagi anak-anak. Salah satu aspek perkembangan anak yang tak kalah penting adalah perkembangan fisik motoriknya. Anak yang sehat tentu akan memudahkannya dalam melakukan segala aktivitas sehari-hari yang dilalui anak tersebut. Perkembangan fisik motorik yang baik dan sesuai dengan tahapan perkembangannya juga tentu sangat penting dalam proses pematangan perkembangannya dan juga mendukungnya dalam kegiatan sehari- harinya.

Perkembangan fisik motorik yang sesuai dengan tahap perkembangan seusianya tentu akan membuat anak menjadi percaya diri, memudahkannya melakukan aktivitas sehari-hari, memudahkannya dalam mengurus dirinya sendiri dan lain sebagainya. Itulah mengapa pentingnya perkembangan aspek motorik tersebut. Semakin baik perkembangan fisik motoriknya maka semakin baik pula ia dalam melakukan aktivitas mengenai kegiatan mengembangkan fisik motoriknya. Namun sebaliknya, jika motorik anak terhambat atau belum berkembang sebagaimana mestinya akan menghambat segala aktivitas sehari-hari anak tersebut. Itulah mengapa perlunya kegiatan atau aktivitas yang dapat mengembangkan motorik anak. Menurut Cratty yang dikutip oleh Faeruz, dkk dikatakan bahwa bahwa motorik halus berkaitan dengan kematangan mekanisme otot syaraf yang memberikan penampilan progresif pada keterampilan motorik, seperti kegiatan literasi dan berbagai kegiatan akademik lainnya, agar anak memiliki kesiapan dalam memasuki pendidikan lebih lanjut (Faeruz, dkk, 2019)

Motorik merupakan terjemahan dari kata "motor" yang menurut Gallahue adalah suatu dasar biologi atau mekanika yang menyebabkan terjadinya suatu gerak. Kemudian gerak (movement) adalah kulminasi dari suatu tindakan yang didasarkan oleh proses motorik. Motorik disini bukan hanya sekedar gerak yang hanya semata-mata berhubungan dengan gerak seperti kita lihat sehari-hari, yakni geraknya anggota tubuh (tangan, lengan, kaki dan tungkai) melalui alat gerak tubuh (otot dan rangka). Tetapi gerak yang didalamnya melibatkan fungsi motorik seperti otak, syaraf, otot dan rangka (Samsudin, 2008). Perkembangan motorik anak sangat penting untuk membantunya dalam melakukan aktivitas sehari-hari, baik 
kemampuannya menolong dirinya sendiri maupun dalam berinteraksi dengan orang lain. Motorik terbagi menjadi 2 yaitu motorik kasar dan motorik halus.

Motorik kasar merupakan gerak anggota badan secara kasar atau keras. Laura E. Berk menjelaskan bahwa semakin anak menjadi dewasa dan kuat tubuhnya (Mulyani, 2018). Motorik kasar membutuhkan sedikit tenaga dalam menggerakkan, seperti misalnya melompat, berlari, memanjat, menendang bola dsb. Sedangkan Motorik halus adalah gerakan yang hanya melibatkan bagian-bagian tubuh tertentu saja yang dilakukan oleh otot-otot kecil, seperti ketrampilan menggunakan jarijemari tangan dan gerakan pergelangan tangan yang tepat. Gerakan motorik halus yang terlihat ketika di usia dini khususnya di usia taman kanak-kanak, antara lain anak mulai dapat melakukan kegiatan sehari-hari seperti bertepuk tangan, memetik jarinya, menyikat gigi, menyisir rambut, membuka dan menutup resleting, memakai sepatu sendiri, mengancingkan pakaian dan sebagainya. Oleh karena itu, setiap gerakan yang dilakukan anak sesederhana apapun itu, sebenarnya merupakan hasil dari pola interaksi yang kompleks berbagai bagian dan sistem dalam tubuh yang dikontrol oleh otak.

Motorik halus adalah suatu kemampuan dalam pengorganisasian otot- otot kecil seperti jari jemari, tangan, dan mata yang membutuhkan kecermatan antara mata dengan tangan. Semakin baik kemampuan motorik halus anak, maka semakin baik pula ia dalam melakukan aktivitas sehari-harinya maupun aktivitas pembelajaran di kelas. Ketika kemampuan motorik halus anak belum berkembang maka akan menyulitkan anak dalam melakukan aktivitas mengembangkan motorik halusnya. Kegiatan yang dapat dilakukan dalam mengembangkan motorik halus anak salah satunya adalah dapat dilakukan dengan melakukan kegiatan pembelajaran dengan kegiatan mozaik.

Dari hasil observasi di lapangan pada anak kelompok B3 RA Perwanida 2 Palembang dengan jumlah subjek 18 orang anak. Ketika peneliti melakukan observasi dilapangan, peneliti melakukan pengamatan dengan melalui kegiatan mengembangkan motorik halus seperti melipat, menempel, mewarnai, menganyam, menyusun puzzle, dan lain sebagainya. Hasil pengamatan tersebut menunjukkan bahwa perkembangan motorik halus anak masih belum berkembang sebagaimana mestinya, yang ditandai dengan 1) terdapat 13 dari 18 anak belum berkembangnya kemampuan dalam mengontrol jari-jemari: 2) terdapat 15 dari 18 anak belum berkembang ketangkasan jari-jemari dan tangan: 3) terdapat 14 dari 18 anak yang belum berkembang keterampilan menggunakan media dengan koordinasi antara mata dan tangan.

Berdasarkan data yang dihasilkan dari observasi tersebut maka dapat disimpulkan bahwa penyebab belum berkembangnya motorik halus anak dikarenakan proses pembelajaran di kelas yang lebih mengutamakan akademik anak saja. Misalnya kegiatan di kelas selalu menulis, membaca dan menghitung 
sehingga anak mudah bosan dengan kegiatan tersebut dan membuat motorik halus anak belum berkembang. Karena orangtua dan masyarakat juga menuntut anaknya bisa membaca menulis dan menghitung sehingga mengharuskan guru melakukan kegiatan calistung setiap harinya seperti misalnya menulis angka huruf-huruf abjad dan sebagainya. Sedangkan sangat jarang guru melakukan kegiatan yang dapat mengembangkan motorik halus anak dan juga kurang adanya inovasi pembelajaran dan media pembelajaran yang dilakukan, serta kurangnya aktivitas atau kegiatan yang dapat mengembangkan aktivitas motorik halus anak di kelas. Kegiatan dilakukan hanya itu-itu saja, guru juga kurangnya berinisiatif dalam pembuatan kegiatan pembelajaran di kelas sehingga motorik halus anak belum terangsang akibatnya motorik anak belum berkembang.

Tyasari dalam Dewi dkk menyatakan bahwa, mozaik merupakan kerajinan yang dibentuk dari kepingan atau pecahan keramik, kaca atau kertas dalam komposisi warna tertentu. Mozaik juga dapat berupa elemen-elemen yang disusun dan direncanakan diatas permukaan bidang datar. Elemen-elemen mozaik dapat berupa benda padat dalam bentuk lempengan, kubus-kubus, kepingan-kepingan kertas (Dewi dkk, 2015). Selanjutnya Rulmania menyatakan bahwa Mozaik adalah sebuah karya seni yang terbuat dari elemen elemen yang disusun dan ditempelkan dengan perekat di atas sebuah permukaan bidang (Rulmania \& Zulminiati, 2019). Dengan kegiatan mozaik anak dapat mengembangkan berbagai aspek perkembangan salah satunya adalah perkembangan motorik halusnya, selain itu kegiatan mozaik ini dapat menyenangkan dan juga memiliki daya tarik tersendiri. Pola gambar yang menarik, serta bahan yang ditempelkan dapat berwarna-warni membuat anak menjadi tidak bosan dengan kegiatan tersebut. Dalam kegiatan mozaik juga menggunakan bahan yang praktis dan mudah di dapatkan dalam kehidupan seharihari membuat kegiatan mozaik semakin baik digunakan, dan juga dapat mengembangkan banyak aspek perkembangan. Salah satunya adalah mampu mengembangkan motorik halus anak. Berdasarkan penelitian yang dilakukan oleh Rulmania dan Zulmiati, menyatakan bahwa kegiatan mozaik mempunyai pengaruh signifikan motorik halus anak (Rulmania \& zulminiati, 2019). Hal ini menunjukan ada hubungan yang erat antara kegiatan mozaik dan motorik halus anak.

Kegiatan mozaik bisa menggunakan dengan bahan-bahan lainnya yang mudah didapatkan dan praktis. Melalui kegiatan mozaik ini perkembangan motorik halus anak dapat dilatih dan berkembang. Karena dengan kegiatan mozaik anak dilatih untuk mengkoordinasikan antara jari- jemari, pergelangan tangan, serta koordinasi antara mata melalui berbagai kegiatan salah satunya adalah dengan melakukan kegiatan mozaik ini.

Hasil dari permasalahan tersebut, peneliti ingin meningkatkan kemampuan motorik halus anak melalui kegiatan mozaik, karena dengan kegiatan mozaik ini anak memiliki kemampuan dalam mengontrol jari-jemari, kemampuan anak dalam 
ketangkasan jari-jemari tangan, dan keterampilan menggunakan media dengan koordinasi antara mata dan tangan dalam melakukan kegiatan mozaik.

\section{Metode}

Penelitian ini menggunakan penelitian tindakan dengan pendekatan kualitatif deskriptif yaitu merupakan proses yang mengevaluasi kegiatan proses belajar mengajar yang dilaksanakan secara sistematik. Pada penelitian ini desain penelitian yang digunakan adalah penelitian tindakan kelas, yang merupakan proses pengkajian masalah di dalam kelas melalui refleksi diri dalam upaya untuk memecahkan masalah tersebut dengan cara melakukan berbagai tindakan yang terencana dalam situasi nyata serta menganalisis setiap pengaruh dari perlakuan tersebut.

Penelitian tindakan yang digunakan dalam penelitian ini adalah menggunakan model penelitian Kemmis \& McTaggart. Model ini merupakan pengembangan dari model Kurt Lewin. Dalam Kemmis \& McTaggart komponen acting (tindakan) dan observing (pengamatan) dijadikan satu kesatuan. Hal ini didasari bahwa pada kenyataannya penerapan tindakan dan pengamatan tidak dapat dipisahkan. Dua kegiatan ini merupakan kegiatan yang dilakukan dalam waktu yang bersamaan. Keempat komponen dalam model Kemmis \& McTaggart dipandang sebagai suatu siklus, dalam hal ini merupakan suatu putaran kegiatan yang terdiri dari perencanaan, tindakan observasi dan refleksi. Berdasarkan refleksi kemudian disusun rencana (perbaikan), tindakan dan observasi serta refleksi, demikian seterusnya. Banyaknya siklus tergantung pada permasalahan yang dipecahkan (Ani Widayati, 2008).

Dalam teknik analisis data dalam penelitian tindakan dapat dikelompokkan menjadi dua sesuai dengan jenis data penelitian yang diperoleh, yaitu teknik analisis data kualitatif dan teknik analisis data kuantitatif (Jakni, 2017). Analisis data dengan menggunakan teknik deskriptif kualitatif biasa digunakan untuk peningkatan dalam proses pembelajaran melalui berbagai tindakan yang diberikan kepada peserta didik agar merujuk kepada peningkatan objek penelitian atau kualitas yang dimiliki, serta melalui triangulasi data. Sedangkan analisis data kuantitatif biasa digunakan dalam memanfaatkan persentase atau skor dimana merupakan langkah pertama dari semua keseluruhan proses analisis. Data dalam analisis data dengan menggunakan nilai rata-rata pada setiap anak, dan pada saat ketuntasan belajar anak.

\section{Hasil dan Pembahasan}

Peneliti menyajikan mengenai berbagai data dan fakta yang dihasilkan pada penelitian yang dilakukan dalam setiap siklusnya yang terdiri dari perencanaan, pelaksanaan, observasi, dan refleksi. Hasil tes yang dilakukan pada penelitian ini adalah dilakukan secara tertulis yang dilaksanakan dalam dua siklus, yaitu siklus I 
dan Siklus II. Dalam penelitian ini peneliti menggunakan rumus persentase untuk melihat peningkatan perkembangan motorik halus anak. Pertama peneliti melakukan prasiklus dimana dalam tahapan prasiklus tersebut peneliti menjadikan prasiklus sebagai acuan untuk melihat penilaian awal perkembangan motorik halus anak dan juga untuk melihat perbandingan antara penilaian pada siklus I dan Siklus II. Peneliti menggunakan kegiatan mozaik untuk meningkatkan kemampuan motorik halus anak kelompok B di RA Perwanida 2 Palembang.

Penelitian ini analisis data yang digunakan adalah kualitatif dan kuantitatif. Teknik analisis data kualitatif dalam penelitian ini adalah mereduksi data, kemudian menyajikan data dan penarikan kesimpulan. Reduksi data dilakukan selama penelitian berlangsung, bahkan langkah ini dilakukan sebelum data benar-benar dikumpulkan. Mereduksi data berarti merangkum, memilih hal-hal yang pokok, memfokuskan pada hal hal penting, dicari tema dan polanya. Dengan demikian data yang direduksi akan memberikan gambaran yang lebih jelas, dan mempermudah peneliti untuk melakukan pengumpulan data selanjutnya supaya peneliti mengetahui ada apa saja yang dibutuhkan terkait tentang penelitian yang terkait yaitu data tentang aspek yang menunjukkan kemampuan motorik halus anak diperoleh berdasarkan catatan lapangan, catatan wawancara, dan catatan dokumentasi.

Pada aspek ketangkasan tangan dan jari-jemari tangan ini, anak-anak sudah mampu menempelkan kepingan mozaik pada pola gambar dengan tepat pada pola gambar, serta anak-anak mampu menempelkan dengan tanpa ada kepingan yang ada diluar garis pola gambar. Anak- anak melakukan kegiatan mozaik dengan teratur serta dapat membuat tangan dan jari-jemari anak dapat mengalami kecepatan pada kemampuan motorik halusnya. Beberapa anak yang masih mengalami kesulitan, namun hampir secara keseluruhan anak sudah baik dalam ketangkasan tangan dan jari-jemarinya.

Kemampuan motorik halus anak pada aspek ketangkasan tangan dan jarijemari tangan anak sudah mengalami peningkatan yang baik, hampir keseluruhan anak sudah mampu menempel kepingan mozaik dengan tanpa ada kepingan yang tertempel di luar garis, serta anak dapat menempel kepingan mozaik dengan tepat pada pola gambar.

Pada aspek keterampilan menggunakan media dengan koordinasi antara mata dan tangan, anak sudah mengalami peningkatan yang baik. Hal ini dapat peneliti lihat, ketika anak melakukan kegiatan mozaik, banyak anak yang sudah mampu menempelkan kepingan mozaik dengan mengkombinasikan warna lebih dari 2 warna, serta mampu mengkombinasikan bentuk pada beberapa pola gambar. Anakanak melakukan kegiatan mozaik dengan baik, dan juga keterampilan menggunakan media akan meningkat dan berkembang sebagaimana mestinya. Aspek keterampilan menggunakan media dengan koordinasi antara mata dan tangan anak-anak sudah 
mengalami peningkatan yang signifikan, anak-anak sudah mampu menempelkan kepingan mozaik dengan kombinasi warna serta kombinasi bentuk.

Kemudian pada analisis data kuantitatif penelitian ini, pada kegiatan prasiklus rata-rata tingkat capaian perkembangan kemampuan motorik halus anak pada kegiatan prasiklus ini baru mencapai kategori persentase (47,66\%) secara keseluruhan. Ada 8 anak dalam kategori Belum Berkembang (BB), kemudian ada 6 anak dalam kategori Mulai Berkembang (MB), ada 3 anak dalam kategori Berkembang Sesuai Harapan (BSH), dan ada 1 anak dalam kategori Berkembang Sangat Baik (BSB) ini artinya masih banyak anak yang kemampuan motorik halus anak belum berkembang sebagaimana mestinya sehingga kemampuan motorik halusnya terganggu.

Sedangkan pada kegiatan siklus I tingkat capaian perkembangan anak pada siklus I ini sudah lebih baik dibandingkan tingkat capaian perkembangan anak pada prasiklus. Pada siklus I ini ada beberapa anak yang mengalami peningkatan di kemampuan motorik halusnya. Meskipun tingkat capaian perkembangan anak belum terlalu meningkat secara signifikan dan belum mencapai angka rata-rata yang ingin dicapai sudah cukup baik yaitu mencapai nilai rata-rata 14,38 atau dalam kategori Mulai Berkembang (59,91\%). Secara keseluruhan ada 7 anak dalam kategori Belum Berkembang (BB), kemudian ada 2 anak dalam kategori Mulai Berkembang (MB), ada 5 anak yang Berkembang sesuai harapan (BSH), dan ada 4 anak dalam kategori Berkembang Sangat Baik (BSB).

Selanjutnya pada kegiatan siklus II rata-rata tingkat capaian perkembangan kemampuan motorik halus anak pada kegiatan siklus II ini sudah dalam kategori Berkembang Sangat Baik yaitu mencapai kategori persentase (80,08\%) secara keseluruhan. Terdapat 2 anak dalam kategori Belum Berkembang (BB), kemudian ada 1 anak dalam kategori Mulai Berkembang (MB), ada 5 anak dalam kategori Berkembang sesuai harapan (BSH), dan ada 10 anak dalam kategori Berkembang Sangat Baik (BSB). Ini artinya kemampuan motorik halus anak sudah sangat berkembang dengan menggunakan kegiatan mozaik.

Hal ini sejalan dengan penelitian yang dilakukan oleh Maghfiroh dkk dalam penelitian tersebut menyatakan bahwa ada pengaruh positif yang signifikan antara teknik mozaik dengan kemampuan motorik halus anak, sehingga teknik mozaik sangat disarankan untuk digunakan dalam pemberian stimulus untuk meningkatkan motorik halus anak (Maghfiroh \& Nurul, 2017). Dalam penelitian lain yang dilakukan oleh Prastiana dan Aminin juga dikatakan bahwa ada pengaruh penerapan teknik mozaik daun kering terhadap kemampuan motorik halus anak. Hal ini menunjukan bahwa penelitian ini sejalan dengan penelitian dan teori-teori sebelumnya (Prastiana\& Aminin, 2014). 


\section{Simpulan}

Berdasarkan hasil penelitian dan pembahasan dapat disimpulkan bahwa kemampuan motorik halus pada anak kelompok B berusia 5-6 tahun di RA Perwanida II Palembang dapat ditingkatkan melalui kegiatan mozaik. Dengan menggunakan kegiatan mozaik tersebut, anak mendapatkan stimulasi peningkatan untuk kemampuan mengontrol tangan dan jari-jemari tangan, ketangkasan tangan dan jari-jemari tangan, keterampilan menggunakan media dengan koordinasi antara tangan dan mata. Peningkatan ini dapat terlihat dari persentase keberhasilan pada kedua siklus selama penelitian ada aspek-aspek berikut: Pada proses kegiatan mozaik dalam mengembangkan motorik halus anak, sudah mengalami perubahan yang baik, anak-anak sudah terbiasa melakukan kegiatan mozaik sehingga memudahkan anak-anak menyelesaikan kegiatan dengan baik dan tersusun. Anakanak sudah mampu menyelesaikan kegiatan mozaik dengan sendiri dan tanpa bantuan dari guru. Karena setiap melakukan kegiatan, guru selalu memberikan motivasi juga mencontohkan kegiatan secara langsung sehingga memudahkan anakanak menyelesaikannya dengan baik. menempelkan kepingan mozaik dengan tepat pada pola gambar.

Hasil dari proses kegiatan mozaik anak sudah mengalami peningkatan, terutama dalam peningkatan kemampuan motorik halusnya, pada kegiatan prasiklus rata-rata tingkat capaian perkembangan kemampuan motorik halus anak pada kegiatan prasiklus hanya mencapai angka persentase $47,66 \%$ atau pada kategori Belum Berkembang. Pada siklus I ini ada beberapa anak yang mengalami peningkatan di kemampuan motorik halus dan mencapai angka persentase 59,91\% atau dalam kategori Mulai Berkembang. Kemudian angka persentase yang dicapai anak pada kemampuan motorik halus pada kegiatan siklus II mencapai angka persentase $80,08 \%$ atau dalam kategori Berkembang .

\section{Daftar Rujukan}

Brian, Ali, Adam Pennell, Sally Taunton, Angela Starrett, Candice HowardShaughnessy, Jacqueline D. Goodway, Danielle Wadsworth, Mary Rudisill, and David Stodden. (2019). “Motor Competence Levels and Developmental Delay in Early Childhood: A Multicenter Cross-Sectional Study Conducted in the USA." Sports Medicine 49 (10). Springer International Publishing: 1609-18. doi:10.1007/s40279-019-01150-5.

Chalpin, J P. (2000), Kamus Lengkap Psikologi, Terjemahan Kartini Kartono (Jakarta: Grafindo Persada)

Dehghan, Leila, Navid Mirzakhani, Mehdi Rezaee, and Mehdi Tabatabaee. (2017). "The Relationship between Fine Motor Skills and Social Development and Maturation." Iranian Rehabilitation Journal 15 (4): 407-14. doi:10.29252/nrip.irj.15.4.407. 
Devi, Anamika, Marilyn Fleer, and Liang Li. (2018). "'We Set up a Small World': Preschool Teachers' Involvement in Children's Imaginative Play." International Journal of Early Years Education 26 (3). Taylor \& Francis: 295-311. doi:10.1080/09669760.2018.1452720.

Dewi, Ni. Pt. Agus Vera, Wayan Wiarta , I. B. Surya Manuab. (2015). Penerapan Model Pembelajaran Numbered Heads Together (Nht) Berbantuan Media Mozaik Untuk Meningkatkan Perkembangan Motorik Halus Pada Anak Kelompok B1 Tk Ganesha Denpasar. Jurnal PG-PAUD Universitas Ganesha. Vol. 3(1)

Duncan, Greg J 1., and Aaron J 2. Sojourner. (2013). “Can Intensive Early Childhood Intervention Programs Eliminate Income- Based Cognitive and Achievement Gaps?" Journal of Human Resources 48 (4): 945-68. doi:10.1353/jhr.2013.0025.

Ernst, Julie A. (2012). "Early Childhood Nature Play: A Needs Assessment of Minnesota Licensed Childcare Providers." Journal of Interpretation Research 17 (1): 7-24.

Faeruz, Ratna, Miratul Hayati \& Huda. (2019). Permainan Kolase untuk meningkatkan Motorik Halus pada Kelompok A TK Muslimat NU Banjarmasin. JECE (Journal of Early Childhood Education). Vol. 1(2)

Fischer, Ursula, Sebastian P. Suggate, and Heidrun Stoeger. (2020). "The Implicit Contribution of Fine Motor Skills to Mathematical Insight in Early Childhood." Frontiers in Psychology 11 (May). doi:10.3389/fpsyg.2020.01143.

Fleer, Marilyn. (2009). "Understanding the Dialectical Relations between Everyday Concepts and Scientific Concepts within Play-Based Programs." Research in Science Education 39 (2): 281-306. doi:10.1007/s11165-008-9085-x.

Jakni. (2017), Penelitian Tindakan Kelas, (Bandung: Alfabeta)

Maghfuroh, Lilis \& Nurul Khotimah. (2017). Pengaruh Teknik Mozaik terhadap Perkembangan Motorik Halus Anak Prasekolah Jurnal Sain Med. Vol.9 (1)

Mcintyre, Laura Lee, and Leah K Phaneuf. 2017. "A Three-Tier Model of Parent Education in Early Childhood Applying a Problem-Solving Model." Topics in Early Childhood Special Education 27 (4): 214-22.

Muharrar, S., \& Verayanti, S. (2013), Kreasi Kolase,Montase, Mozaik Sederhana, (Semarang: Erlangga Group)

Mulyani, N. (2018), Perkembangan Dasar Anak Usia Dini, (Yogyakarta : Gava Media)

Munroe, Elizabeth, and Alanna MacLellan-Mansell. (2013). "Outdoor Play Experiences for Young First Nation Children in Nova Scotia: Examining the Barriers and Considering Some Solutions." Journal of Childhood Studies 38 (2): 25-33. doi:http://dx.doi.org/10.18357/jcs.v38i2.15448.

Mutiah, D. (2010), Psikologi Bermain Anak Usia Dini, (Jakarta : Kencana Prenada Media Group)

Nazir, M. (2011), Metode Penelitian, (Bogor : Ghalia Indonesia) 
Pamadgi, H. (2013). Seni Keterampilan Anak, (Tanggerang Selatan : Universitas Terbuka)

Prastiana, Devita Dwi\&Zainul Aminin. (2017). Pengaruh Penerapan Teknik Mozaik Daun Kering Terhadap Kemampuan Motorik Halus Anak Kelompok B Tk Qoshrul Ubudiyah Surabaya. PAUD Teratai. Vol. 3 (1)

Rushton, Stephen. (2011). "Neuroscience, Early Childhood Education and Play: We Are Doing It Right!" Early Childhood Education Journal 39 (2): 89-94. doi:10.1007/s10643-011-0447-z.

Rulmania, Rici \& Zulminiati. (2019). Efektivitas Mozaik Bahan Alam (Sisik Ikan) Terhadap Motorik Halus Anak. Jurnal PG-PAUD Trunojoyo. Vol.6 (2)

Samsudin, (2008) Pembelajaran Motorik Di Taman Kanak-Kanak, (Jakarta: Prenamedia Group)

Santrock, John W., (2011), Psikologi Pendidikan, (Jakarta Selatan: Salemba Humanika) Sheridan, Kathleen Mary, and Melissa A. Kelly. (2012). “Teaching Early Childhood Education Students Through Interactive Scenario-Based Course Design." Journal of Early Childhood Teacher Education 33 (1): 73-84. doi:10.1080/10901027.2011.650786.

Soetjiningsih, C.H. (2012). Perkembangan Anak, (Jakarta: Prenada Media Group)

Sugiyono. (2017). Metode Peneltian Pendidikan. (Bandung: Alfabeta)

Sujiono, Yuliani Nurani. (2013). Konsep Dasar Pendidikan Anak Usia Dini. (Jakarta Barat: Indeks)

Susanto, A. (2015). Bimbingan \& Konseling di Taman Kanak-Kanak, (Jakarta: Prenamedia Group)

Taverna, Livia, Marta Tremolada, Barbara Tosetto, Liliana Dozza, and Zanin Scaratti Renata. (2020). "Impact of Psycho-Educational Activities on Visual-Motor Integration, Fine Motor Skills and Name Writing among First Graders: A Kinematic Pilot Study." Children 7 (4): 27. doi:10.3390/children7040027.

Upton, P. (2012). Psikologi Perkembangan, (Jakarta : Erlangga)

Undang- Undang Republik Indonesia. Nomor 20. Tahun 2003. Sistem Pendidikan Nasional.

Yeni, R., \& Euis, K. (2010). Strategi Pengembangan Kreativitas Pada Anak. (Jakarta : Kencana Prenada Media Group)

Yus, Anita. (2011). Penilaian Perkembangan Belajar Anak Taman Kanak-Kanak (Jakarta:Prenadamedia Group,)

Yusuf, Syamsu L.N., Nani M. Sugandhi, (2013) Perkembangan Peserta Didik, (Jakarta: Rajawali Pers) 